\title{
Growing Skull Fracture in an Infant: A Case Report
}

\author{
Bebek Hastanın Büyüyen Kafatası Kırı̆̆ı: Bir Olgu Sunumu \\ ๑ Aykut Akpınar, • Mehmet Nihat Dinçbal, • Bekir Mahmut Kılınç \\ University of Health Sciences, Haseki Training and Research Hospital, Clinic of Neurosurgery, Istanbul, Turkey
}

\begin{abstract}
Growing skull fracture (GSF) is a rare complication of cranio-cerebral injuries in infants and children under three years of age. Falls and blunt force head trauma are the most frequent causes of head injuries. GSF usually results from a linear calvarial fracture, however, it may also occur due to a closed-head injury. The most common symptom is scalp swelling without progressive tenderness or pain. The most common site of GSF is the parietal region. GSF may cause epilepsy, neurologic disorders and calvarial asymmetry. Duraplasty in early period of GSF is recommended in order to have better results. Here, we report a 15-month-old girl with parietal bone fracture who was followed closely both clinically and radiologically and underwent surgical repair of GSF and enlargement of the dural defect.
\end{abstract}

Keywords: Growing skull fracture, children, sequel of trauma, cephalohematoma, dural tear

\section{Introduction}

John Howship described growing skull fracture (GSF) in the $18^{\text {th }}$ century for the first time (1-3). The etiopathologies of GSF have not been fully understood. Posttraumatic skull defect diastasis may occur because of arachnoid herniation of dural tears and cerebrospinal fluid (CSF) leakage from the fracture line (4-8).

GSF is a rare complication associated with traumatic skull fractures in children under three years of age GSF (9-11). GSF has been reported to occur in 0.05\%-1.6\% of cases $(1,4,8-12)$. The parietal region of the skull is the most commonly affected area $(1,13)$.

Seizures, neurological deficits, and pulsatile swelling are the most common presenting features.

Early diagnosis and prompt surgical intervention are necessary for the prevention of progressive brain damage associated with GSF. The time interval between head
Büyüyen kafatası kırıkları (GSF); yenidoğan ve üç yaş altı çocuklarda, kafatası ve serebral travma sonrası oldukça nadiren ortaya çıkan komplikasyonlardır. Kaza şekli çoğunlukla yüksekten düşme veya ağır bir obje ile çarpışma sonrası oluşan kafatası yaralanmasıdır. Genellikle düz kafatası kırıklarından oluşmakla birlikte, kapalı kafa travmasında da oluşur. En önemli semptom; saçlı deride, ilerleyici hassasiyeti veya ağrısı olmayan şişliktir. Parietal bölge en sık lokalizasyondur. GSF nörolojik defisitin ilerlemesine ve kraniyal asimetriye neden olur. GSF'de erken dönemde cerrahi olarak dura yırtık tamiri yapılması klinik sonuçların daha iyi olması için önerilmektedir. Bu çalışmada, parietal kemik kırı̆̆ını klinik ve radyolojik olarak yakından takip ettiğimiz 15 aylık bir kız çocuğu sunulmaktadır. Altı ay sonra, GSF ve dura yırtığının genişledigi gözlendi. Cerrahi onarım yapıldı.

Anahtar Sözcükler: Büyüyen kafatası kırıkları, çocuk, travma sekeli, sefal hematom, dura yırtığı

trauma and diagnosis varies between a few days and several years $(6,8,14)$.

Plain radiography and computed tomography $(\mathrm{CT})$ are the methods of choice for the diagnosis of GSF $(6,9,15,16)$. Magnetic resonance imaging (MRI) scans provide details about brain tissue damage, herniation and CSF leakage. $(9,15,17)$.

If GSF is not promptly treated, seizures or neurologic disorders associated with brain injury may occur $(1,5,9)$. Duraplasty and cranioplasty are treatment modalities. $(1,4,8,9)$.

\section{Case}

A 15-month-old girl with cephalohematoma in the right parietal region was admitted to our emergency department. She had a minor head injury. On examination, she had cephalohematoma in the right parietal region and
Address for Correspondence/Yazışma Adresi: Aykut Akpınar

University of Health Sciences, Haseki Training and Research Hospital, Clinic of Neurosurgery, İstanbul, Turkey

Phone: +90 5336109583 E-mail: aykut1953@yahoo.com ORCID ID: orcid.org/0000-0002-5049-3259

Received/Geliş Tarihi: 08 October 2017 Accepted/Kabul Tarihi: 27 January 2018
'Copyright 2018 by The Medical Bulletin of University of Health Sciences Haseki Training and Research Hospital
The Medical Bulletin of Haseki published by Galenos Yayınevi.

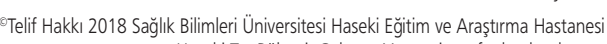
Haseki Tıp Bülteni, Galenos Yayınevi tarafından basılmıştır. 
CT scans showed a fracture line between the parietal bone and the frontal bone (Figure 1). Neurologic exam was normal. Three months later, follow-up MRI scans showed a dural tear and CT scan showed enlargement of diastasis of the parietal bone (Figure 2). After six months of the trauma, X-ray showed a bone diastasis greater than $4 \mathrm{~mm}$ (Figure 3), and pulsative swelling of the parietal bone region. After written informed consent was taken from her family, surgery was performed.

Under general anesthesia, we encircled the parietal fracture defect with Kerrison rongeur (Figures 4, 5). Duraplasty was done by galeal graft (Figures 6,7 ). The patient had an uneventful recovery. There were no complications, such as hematoma and CSF leak.

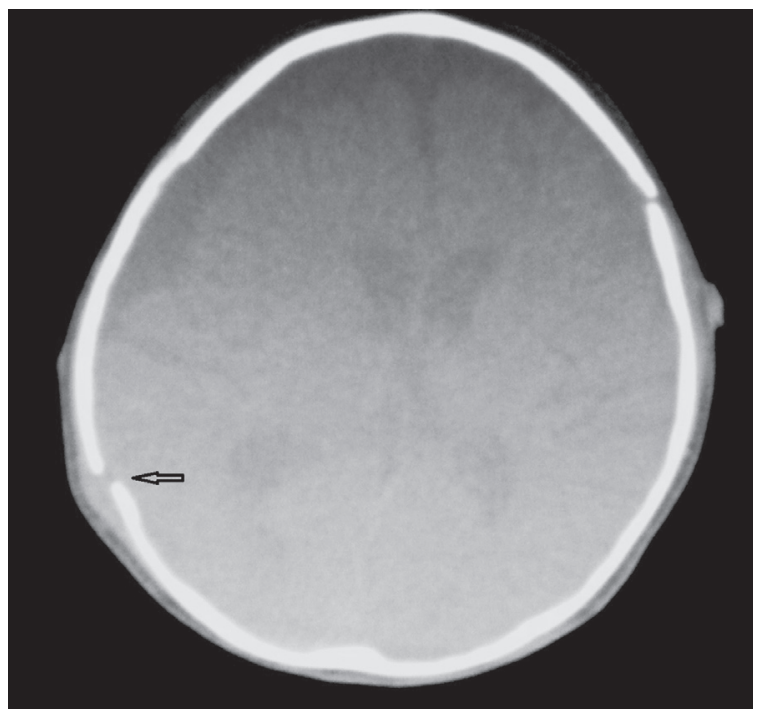

Figure 1. Computed tomography scans showed the parietal to frontal fracture line

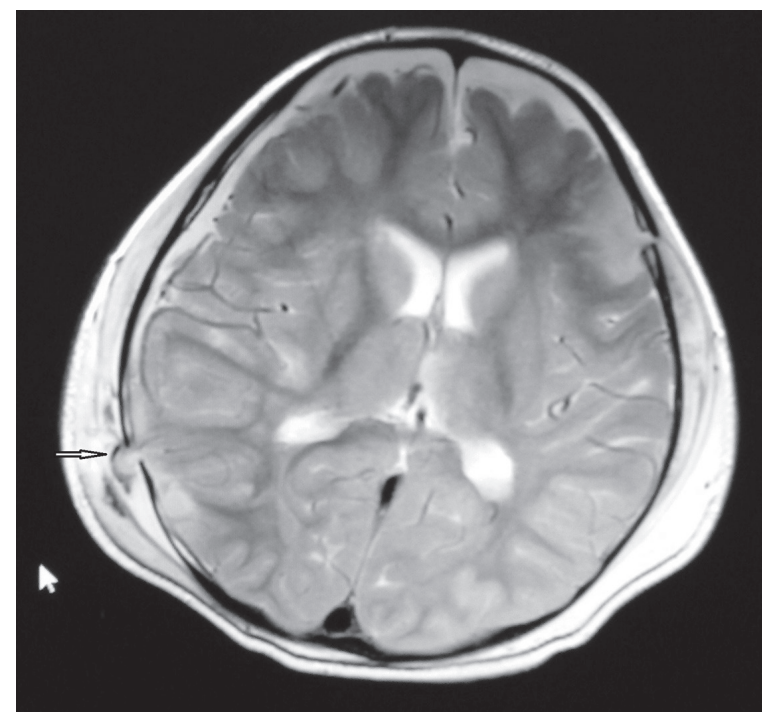

Figure 2. Magnetic resonance imaging scans showed dural tear

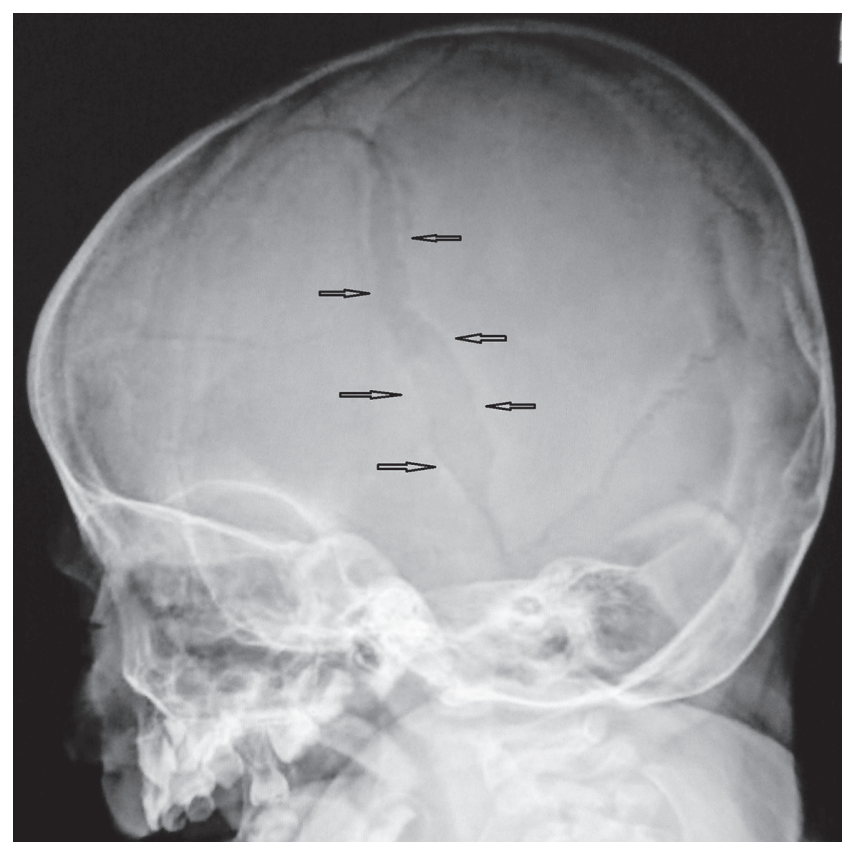

Figure 3. X-ray showed the bone diastasis more than $4 \mathrm{~mm}$

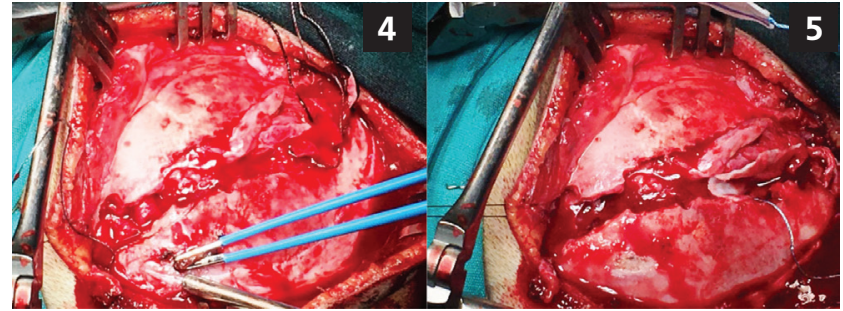

Figure 4, 5. The bony and dural defect

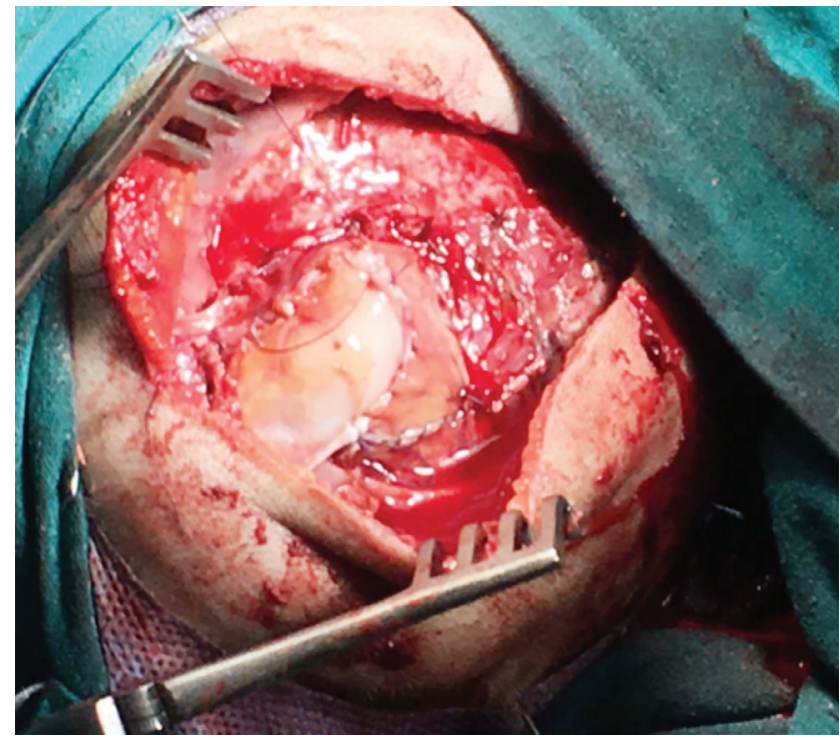

Figure 6. Dural margins were identified all around and watertight duraplasty 


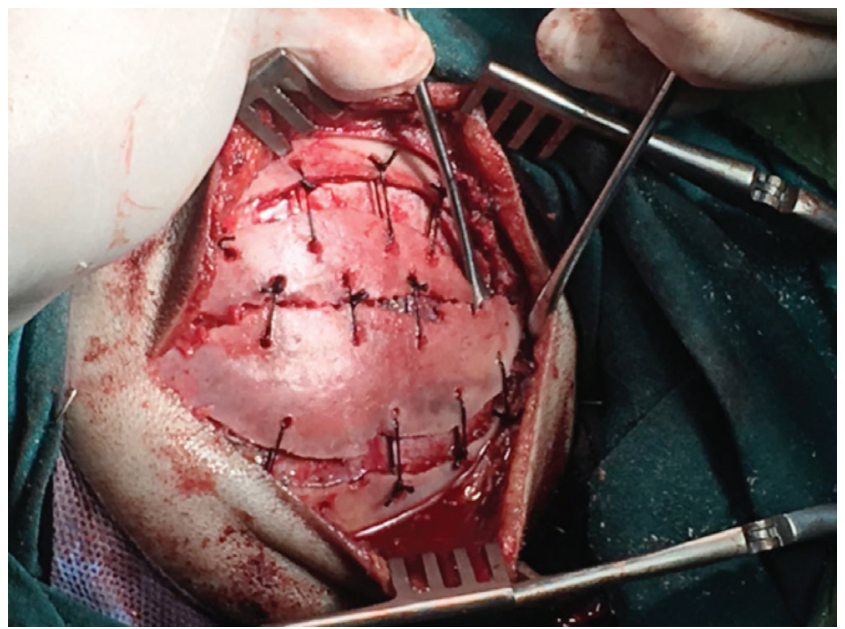

Figure 7. Cranioplasty

\section{Discussion}

There are many terminologies describing GSF (leptomeningeal cyst, traumatic ventricular cyst, etc.) $(1,5,18)$.

Young children especially those under three years of age are mostly affected $(1,4,19)$. Adult manifestation is rare 1 it has been reported that $90 \%$ of cases of GSF occurred in children younger than three years of age and more than 50\% occurred in those below the age of 12 months (4).

Fall from a height is the most common cause of GSF and cephal haematoma is usually at trauma side and bone diastasis and dural tears are the main start points of GSF $(1,4,5,19)$. Parietal bone is the most commonly affected area $(1,10,19)$.

The etiopathogenesis of GSF has not been fully understood. It has been described that after a head trauma causing skull bone fracture with underlying dural tear, healing of the fracture margins is hindered by an intercranial hypertension syndrome and pulsation of the CSF, and with invagination and entrapment of arachnoids into a diastatic fracture, bone diastasis associated with leptomeningeal herniation occurs $(18,20)$.

Tightly dural adhesion to the calvarium and the skull bones may be the cause of GSF $(8,9,16)$.

Early diagnosis of GSF is important $(1,13,21)$. Radiological methods are useful in the diagnosis. X-ray scans can show the bone fracture lines and defects $(4,19)$. CT scans show the exact location and enlargement of bone defect and possible brain tissue damage $(9,10)$. CSF leak, dural tear and herniation of the brain can be detected via MRI scans $(1,9,11)$.

In their study including seven patients, Naim-UrRahman found three main types of GSF based on CT and surgical findings, etiopathogenesis, and management strategies required: a leptomeningeal cyst in three patients, damaged and gliotic brain in three patients, and a porencephalic cyst extending through the skull defect into the subgaleal space in two patients.

Duraplasty is the main point $(22,23)$. Dural tears with pulsation of CSF cause bone diastasis $(4,19)$. We should first see the defect and then, duraplasty should be done $(9,19)$. After duraplasty, cranioplasty should be performed, but if a herniated gliotic parenchymal/leptomeningeal cyst is present, the surgical treatment can include resection of the tissue and the cyst $(1,4,9,19)$.

GSF may be the cause of seizures in $10-50 \%$ of patients $(1,9,11,13,19)$. Seizures mostly occur within two years after trauma.

The incidence of neurological deficits associated with GSF is between $10 \%$ and $65 \%(1,9,11,19)$.

Mortality rate is between $0 \%$ and $8 \%$ (anesthesia- and meningitis-related) $(1,4,9,10,19)$. In order to protect the brain and lessen the seizures, surgery should be done immediately $(1,9,10,19)$.

Multiple head trauma, large defects crossing the superior sagittal sinus, delayed surgery, age over eight years and female gender are the factors for poor prognosis. Parent education level and awareness are important for early detection of GSF (1).

Infants and children with linear skull fractures must be followed up closely, both clinically and radiologically. In the presence of $\mathrm{CT}$ finding of bone diastasis and MRI finding of dural tear herniation of brain matters, surgery should be performed promptly to prevent neurological deficit or seizures.

\section{Authorship Contributions}

Surgical and Medical Practices: A.A., B.M.K. Concept: A.A., M.N.D., B.M.K. Design: A.A., M.N.D., B.M.K. Data Collection or Processing: A.A. Analysis or Interpretation: A.A. Literature Search: A.A. Writing: A.A.

Conflict of Interest: No conflict of interest was declared by the authors.

Financial Disclosure: The authors declared that this study received no financial support.

\section{References}

1. Prasad GL, Gupta DK, Mahapatra AK, Borkar SA, Sharma BS. Surgical results of growing skull fractures in children: a single centre study of 43 cases. Childs Nerv Syst 2015;31:269-77.

2. Robert O, Pitmann T. Youman's Neurological Surgery. 6 th ed. Philadelphia: Elsevier; 2011.p.2184-6.

3. Pia HW, Tonnis W. Die Washsende Schadelfractur des Kindensalters. Zentralbl Neurochir 1953;13:1-23.

4. Ersahin Y, Gülmen V, Palali I, Mutluer S. Growing skull fractures (craniocerebral erosion). Neurosurg Rev 2000;23:139-44. 
5. Reddy DR. Growing skull fractures: guidelines for early diagnosis and effective operative management. Neurol India 2013;61:455-6.

6. de P Djientcheu $V$, Njamnshi AK, Ongolo-Zogo P, et al. Growing skull fractures. Childs Nerv Syst 2006;22:721-5.

7. Baldawa S. Remote intracranial hemorrhage following surgery for giant orbitofrontal growing skull fracture: A lesson learnt. J Pediatr Neurosci 2016;11:118-20.

8. Singh I, Rohilla S, Siddiqui SA, Kumar P. Growing skull fractures: guidelines for early diagnosis and surgical management. Childs Nerv Syst 2016;32:1117-22.

9. Liu XS, You C, Lu M, Liu JG. Growing skull fracture stages and treatment strategy. J Neurosurg Pediatr 2012;9:670-5.

10. Wang X, Li G, Li Q, You C. Early diagnosis and treatment of growing skull fracture. Neurol India 2013;61:497-500.

11. Diyora B, Nayak N, Kamble H, Kukreja S, Gupte G, Sharma A. Surgical treatment and results in growing skull fracture. Neurol India 2011;59:424-8.

12. Abuzayed B, Tuzgen S, Canbaz B, Yuksel O, Tutunculer B, Sanus GZ. Reconstruction of growing skull fracture with in situ galeal graft duraplasty and porous polyethylene sheet. J Craniofac Surg 2009;20:1245-9.

13. Kingsley D, Till K, Hoare R. Growing fractures of the skull. J Neurol Neurosurg Psychiatry 1978;41:312-8.

14. Zegers B, Jira P, Willemsen M, Grotenhuis J. The growing skull fracture, a rare complication of paediatric head injury. Eur J Pediatr 2003; 162:556-7.
15. Ellis TS, Vezina LG, Donahue DJ. Acute identification of cranial burst fracture: comparison between $\mathrm{CT}$ and MR imaging findings. AJNR Am J Neuroradiol 2000;21:795-801.

16. Simon B, Letourneau P, Vitorino E, McCall J. Pediatric minor head trauma: indications for computed tomographic scanning revisited. J Trauma 2001;51:231-7.

17. Husson B, Pariente D, Tammam S, Zerah M. The value of MRI in the early diagnosis of growing skull fracture. Pediatr Radiol 1996;26:744-7.

18. Jain S, Gandhi A, Sharma A, Mittal RS. Growing skull fracture with cerebrospinal fluid fistula: A rare case report and its management strategies. Asian J Neurosurg 2015;10:229-31.

19. Gupta SK, Reddy NM, Khosla VK, et al. Growing skull fractures: a clinical study of 41 patients. Acta Neurochir (Wien) 1997;139:928-32.

20. Drapkin AJ. Growing skull fracture: a posttraumatic neosuture. Childs Nerv Syst 2006;22:394-7.

21. Halliday AL, Chapman PH, Heros RC. Leptomeningeal cyst resulting from adulthood trauma: case report. Neurosurgery 1990;26:150-3.

22. Naim-Ur-Rahman, Jamjoom Z, Jamjoom A, Murshid WR. Growing skull fractures: classification and management. $\mathrm{Br}$ J Neurosurg 1994;8:667-79.

23. Ergün R, Okten Al, Akdemir G, Beskonakli E, Gürsoy F, Taskin Y. Cranio-cerebral erosion: delayed diagnosis and treatment. Neurosurg Rev 1998;21:249-53. 